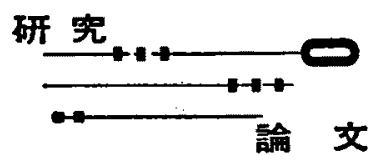

\title{
638. 加速のない垂直気液二相流の摩摖エネルギー消散
}

\author{
安 達公 道*, 岡 崎 元 昭*
}

\author{
（1975年 3 月28日 受 理） \\ (1976年 5 月13日 再受理) \\ Frictional Energy Dissipation in Two Phase Flow \\ By Hiromichi ADACHI and Motoaki OKAZAKI
}

\begin{abstract}
In non-accelerated upward two phase flow, irreversible energy dissipation is caused by wall friction and interphase friction between gas and liquid due to slip. These two components of energy dissipation are deduced from two different methods; one is from equations of force and energy balance and the other from analysis of gedanken-experiment on the gravitational head of two phase flow.

Frictional force due to wall must have same magnitude per unit volume in both liquid and gas. Moreover, the characteristics of energy dissipation were investigated in a circular pipe and in nuclear fuel assemblies using the data of pressure loss. It is found that these characteristics show strong dependence on flow pattern and rod bundle arrangement.
\end{abstract}

KEYWORDS: two phase flow, energy losses dissipation, slip, interphase friction, nuclear fuel assemblies, wall friction, gas, liquid

\section{I. 緒言}

BWR 炉心の上らな複雜な形状の流路の二相流摩擦 損失を，円管や二重管での実験結果を用いて推定する ことが多いが，二相流の摩擦損失特性は流路の形状， 寸法などによって一般に異なるるのである。このこと をより詳しく検討するための足がかりの一つとして， 気相と液相のすべりによって生ずる非可逆エネルギー 消散の問題をとりあげる。

単相流に批いては，管暨に対して流体が移動するこ とに基つく壁面摩擦力と流体の平均移動速度との積に 相当する非可逆エネルギー消散を生ずる。ここに，壁 面摩擦力は流路に生ずる摩擦王力損失から求められ る。非可逆エネルギー消散そのるのを微視的に見れ ば，粘性や渦のために流体内部で発生するものである が，その粘性中渦に上る運動量交換に基つ゚くせん断力 が最終的に壁面に伝えられるので，巨視的には上記の 形で算出できるのである。

さて，二相流においては，一般に気液の密度差のた めにすべりを生ずるので, 壁と流体との相対運動に基
つく非可逆エネルギー消散のほかに，気液のすべりに 基つ゚く非可逆エネルギー消散を生ずる。これを相間磨 摖エネルギー消散と名づけ，これに対して壁と流体と の相対運動に基つくく方を，壁摩擦エネルギー消散と名

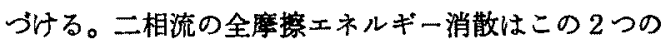
和である。なお，相間摩擦エネルギー消散と壁摩擦工 ネルギー消散とは，微視的にェネルギー消散の生ずる 場所で分類した概念ではない。

相間摩擦エネルギー消散と壁摩擦エネルギー消散と を，実験によって分離して求めることは一般にきわめ て困難である。本報では，加速による圧力降下が無視 できるような，相変化のない垂直気液二相流の相間摩 擦消散之壁摩擦消散とを，殴力降下，ボイド率などの 実測值を用いてそれぞれ算出する方法について，2つ の異なる考光方から出発して，両者が一致して求めら れることを報告する。そして，この計算式に円管流路 および $2 ， 3$ の管束型原子炬燃料体流路に打ける王力 損失測定データを使用して壁摩擦消散と相間摩摖消散

* 日本原子力研究所(Japan At. Energy Res. Inst.) 
とを求めたところ，流動様式あるいは流路特性によっ てこえれらのェネルギー消散の特性が非常に異なるこ とがわかった。

また，二相流の気液各相に作用する壁面摩擦力は， 気相も液相も単位体倩当り，それぞれ等しい力で分配 されることが証明できた。

\section{II . 理 論}

二相流における，流れに沿ら状熊量の变化について 数種類の考察を行い，全非可逆エネルギー消散，壁摩 擦エネルギー消散, 相間摩擦エネルギー消散などが， それぞれどのよらに表現されるかを明らかにする。 な拈，以下の諘諭はすべて，垂直流路を流れる相変 化のない二相流に関するるのであり，かつ流体の加速 が無視できる場合を取り扱っている。

\section{1. 全非可逆エネルキー消散}

(1) 力学的エネルギーの収支式 $d Z$ 区間に存在する気相単位体㺓に関する力のつり 合いを考える。力はすべて上向きを正とし，図の矢印 は垂直上昇流の場合の力の向きを示主(第 1 図参照)。

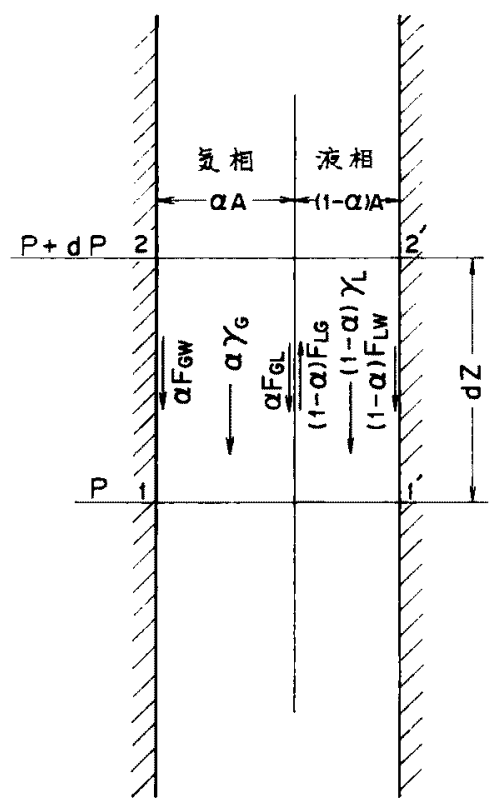

第 1 図 管路の微小区間 $d Z$ Kおける力のつり合い

王力差に基つく力, 重力, 液相か、受ける相間摩擦力 および壁摩擦力がつり合らから，

$$
\frac{d P}{d Z}+r_{a}-F_{a_{L}}-F_{a W}=0
$$

同様に，液相単位体䅡に関するカのつり合いから

$$
\frac{d P}{d Z}+\gamma_{L}-F_{L G}-F_{L W}=0
$$

(1)，(2)式化それぞれ $Q_{\sigma} / A$ および $Q_{2} / A$ を乗し て辺々加え合わせれば, 二相流路単位体積当り, 単位 時間当りの力学的エネルギーの収支式が得られる。す なわち

$$
\begin{gathered}
\frac{Q_{a}+Q_{L}}{A} \cdot \frac{d P}{d Z}+\frac{\gamma_{a} Q_{a}+\gamma_{L} Q_{L}}{A}-\frac{F_{a L} Q_{G}+F_{L O} Q_{L}}{A} \\
-\frac{F_{G W} Q_{a}+F_{L W} Q_{L}}{A}=0
\end{gathered}
$$

ここに，(3) 式左辺の第 3 ，第 4 項は，それぞれ相 間摩摖扰よび壁摩擦力に抗してなした仕事量であり， これらの摩擦によって非可逆的に熱エネルギーに变化 した量を表わす。これは，二相流路単位体積当り，単 位時間当りの全非可逆エネルギー消散 $E_{T}$ と考えるこ とができるから、

$$
E_{T}=-\frac{F_{G L} Q_{G}+F_{L G} Q_{L}}{A}-\frac{F_{G W} Q_{G}+F_{L W} Q_{L}}{A}
$$

で表わされ，(3)式に代入して変形すれば，

$$
\left(Q_{Q}+Q_{L}\right) d P+\left(\gamma_{\sigma} Q_{G}+\gamma_{L} Q_{L}\right) d Z+A E_{T} d Z=0
$$

よって，(5)式より $E_{T}$ は次のように表わされる。

$$
E_{T}=-\frac{Q_{G}+Q_{L}}{A} \cdot \frac{d P}{d Z}-\frac{\gamma_{G} Q_{G}+\gamma_{L} Q_{L}}{A}
$$

$Q_{a}, Q_{L}, d P / d Z$ などを実測することにより，(6) 式を用いて $E_{T}$ を求めることができる。

(2) 全エネルギー保存の式

熱エネルギーと力学的エネルギーにここでは位置エ ネルギー)との和が $d Z$ 区間で保存されていることに 上り,

$$
J d\left(\gamma_{O} Q_{G} h_{\sigma}+\gamma_{L} Q_{L} h_{L}\right)+\left(\gamma_{G} Q_{Q}+\gamma_{L} G_{L}\right) d Z=0
$$

が成り立つ。これに熱力学の一般関係式 $v d P+J T d S=J d h$

を二相流の気液各相について立て，加え合わせると，

$$
\begin{gathered}
\left(Q_{G}+Q_{L}\right) d P+J T d\left(\gamma_{\theta} Q_{G} S_{a}+\gamma_{L} Q_{L} S_{L}\right) \\
=J d\left(\gamma_{a} Q_{G} h_{G}+\gamma_{L} Q_{L} h_{L}\right)
\end{gathered}
$$

これを(7)式に代入して，(5)式と辺々比較すれば，

$$
A E_{T} d Z=J T d\left(\gamma_{\sigma} Q_{O} S_{Q}+\gamma_{L} Q_{L} S_{L}\right)
$$

を得る。壁を通じての熟エネルギーの授受がないこと を考麻すれば，摩擦力に抗してなした仕事は，すべて 熱エネルギーとして流体に䍔収されることがわかる。

\section{2. 壁摩摖エネルギ一消散}

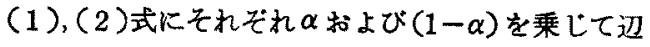
辺加え合わせ，さら作用二反作用の法則 


$$
\alpha F_{a L}+(1-\alpha) F_{L G}=0
$$

および壁摩擦力の定義式

$$
\alpha F_{G W}+(1-\alpha) F_{L W} \equiv F_{W}
$$

を用いて整理すれば，

$$
\frac{d P}{d Z}+\left\{\alpha \gamma_{0}+(1-\alpha) r_{L}\right\}-F_{W}=0
$$

が得られる。(12)式は全王力降下がーッド差と壁摩擦 力との和とつり合らことを示す。ここで、へッド差は, 二検查断面間に存在する流体に作用する重力により生 ずる差珐である。

ところで，(1)，(2)式で表わされるように流路断 面の一部分，例えば夜相部分だけ，あるいは気相部分 だけについて考えれば重力, 相間摩擦力, 壁摩擦力の緸 和が差压とつり合うのである。(12)式では相間摩擦力 が消去された形になっているが，実際にはそれは作用 しているのであって，相間摩摖力の存在が(12)式の表 現形式そのものを可能にしている点に注意しなければ ならない。

さらに，(12)式の両辺に $\left(Q_{a}+Q_{L}\right) / A$ を乗じて

$$
\frac{d P_{\rho}}{d Z}=F_{\text {W }}
$$

とおけば,

$$
\begin{gathered}
\frac{Q_{a}+Q_{L}}{A} \cdot \frac{d P}{d Z}+\frac{Q_{a}+Q_{L}}{A}\left\{\alpha \gamma_{\sigma}+(1-\alpha) \gamma_{L}\right\} \\
-\frac{Q_{a}+Q_{L}}{A} \cdot \frac{d P_{f}}{d Z}=0
\end{gathered}
$$

(14)式の第 1 項は(3)式の第 1 項と同じである。第 2 項は上に述べた理由によりへッド差，すなわち重力拈 よび相間摩擦力に抗して気液二相流体が流れる際にな す仕事量である。第 2 項が単に重力に抗して流れる際 になす仕事量 (( 3 )式の第 2 項)ではなくて，相間摩擦 エネルギー消散項( $(3)$ 式の第 3 項)を含んでいる点 に注意しなければならない。

したがって，(3)式との比較から(14)式第 3 項は， (3)式の第 4 項で表わされるところの二相流体が壁庶 擦力に抗して毎秒なす仕事量に等しくなければならな W。って

$$
E_{W}=-\frac{Q_{a}+Q_{L}}{A} \cdot \frac{d P_{\rho}}{d Z}
$$

は二相流路単位体積当り，単位時間当りの壁摩擦エネ ルギー消散と考えることができる。

(15)式を用いれば，(14)式は

$$
\begin{aligned}
& \left(Q_{a}+Q_{L}\right) d P+\left(Q_{a}+Q_{L}\right)\left\{\alpha \gamma_{a}+(1-\alpha) \gamma_{L}\right\} d Z \\
& +A E_{W} d Z=0
\end{aligned}
$$

(16)式より

$$
E_{\mathbb{W}}=-\frac{Q_{G}+Q_{L}}{A} \cdot \frac{d P}{d Z}-\frac{Q_{G}+Q_{L}}{A}\left\{\alpha \gamma_{G}+(1-\alpha) \gamma_{L}\right\}
$$

よって, $Q_{a}, Q_{L}, \alpha, d P / d Z$ を実測することにより， (17)式から壁摩擦エネルギー消散 $E_{W}$ を求めること ができる。

（13）式では，壁面から流体に作用して壁摩擦力を流 体に体積比例形の力を及ぼす代力勾配に置き換えてい るが,この置换えの意味については第 II-4 節で詳述す る。

\section{3. 相間魔擦エネルギー消散}

(1) 第1法 $\left(E_{T}, E_{\text {T }}\right.$ からの間接導出 $)$

第I-1節で求めた全非可逆エネルギー消散 $E_{\boldsymbol{T}}$ 妒 (3) 式（4)式で示されると拈り，第II-2節で求めた壁摩擦 エネルギー消散 $E_{W}$ と相間摩摖エネルギー消散 $E_{I}$ と の和と考えられる。たたし， $E_{I}$ は $d Z$ 区間の二相流 路単位体積当り，単位時間当りの相間摩摖によるエネ ルギー消散である。したがって（6)，(17)式を用いて 整理すれば，

$$
\begin{aligned}
E_{I} & =E_{T}-E_{W}=\frac{1}{A}\left(\gamma_{L}-\gamma_{G}\right)\left\{(1-\alpha) Q_{Q}-\alpha Q_{L}\right\} \\
& =\alpha(1-\alpha)\left(\gamma_{L}-\gamma_{G}\right)\left(V_{O}-V_{L}\right)
\end{aligned}
$$

（2）第 2 法(思考実駗による直接導出)

(12)式の左辺第 2 項は位重水頭の項であるが，単位 高さ当りの位固水頭差がこのよう火表現される意味を゙ 思考実験で解明してみる

いま,気泡流のよらに, 液相が連続相で, 気相が 分散相であり，かつ連続 相が静止している二相流 を考えてみよう。思考実 験として，第 2 図に示す よらに，すへての気泡を 重さのない針金で管壁に 固定したとしよう。この 时, 気泡に作用する浮力 は，針金の弾珄応力を介 して管壁に伝えられる。 この時の単位高さ当りの 位圈水頭差快，上く知ら れた連通管の䦓題であっ て， $r_{L}$ で表わされる。 次に，気泡を固定した 重さのない針金を切断し てみよ5。今度は針金か ら伝えられる力がない

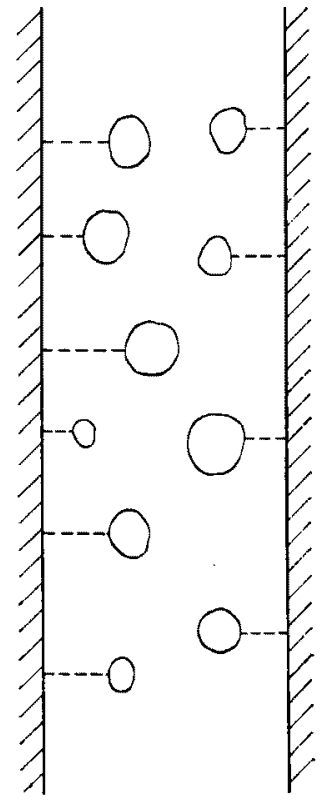

管路内の位置水頭 に関する思考実験 第 2 园 
ら，浮力によって気泡が上昇し始める。その結果，気 夜間の相対速度は，気泡に儌く浮力と流体力学的な抗 カとがつり合うまで増加する。この抗力により水の重 量の一部が支えられるので, 位膡水頭差は $\gamma_{L} よ り$ 抗 カの分たけけさくなる。その結果がよく知られている 上5に $\alpha \gamma_{G}+(1-\alpha) \gamma_{L}$ なのであるから, 液相単位体 積当りに作用する抗力, すなわち相間摩擦力 $F_{L Q}$ は,

$$
\begin{aligned}
F_{L G} & =\gamma_{L}-\left\{\alpha \gamma_{G}+(1-\alpha) \gamma_{L}\right\} \\
& =\alpha\left(\gamma_{L}-\gamma_{G}\right)
\end{aligned}
$$

作用二反作用の法則(10)式を用いれば，気相について

$$
\begin{aligned}
F_{O L} & =\gamma_{G}-\left\{\alpha \gamma_{G}+(1-\alpha) r_{L}\right\} \\
& =-(1-\alpha)\left(\gamma_{L}-\gamma_{a}\right)
\end{aligned}
$$

ゆえに, 相間摩擦力に抗して気相がなす仕事は, 二相 流路単位体積当り，単位時間当り

$$
E_{I G}=\frac{Q_{a}}{A}(1-\alpha)\left(\gamma_{L}-\gamma_{a}\right)
$$

同様に，液相のなす仕事は

$$
E_{I L}=-\frac{Q_{L}}{A} \alpha\left(\gamma_{L}-\gamma_{0}\right)
$$

ゆ穴に， $E_{I}$ は

$$
\begin{aligned}
E_{I} & =E_{I G}+E_{I L}=\frac{1}{A} \alpha(1-\alpha)\left(\gamma_{L}-\gamma_{O}\right)\left(\frac{Q_{Q}}{\alpha}-\frac{Q_{L}}{1-\alpha}\right) \\
& =\alpha(1-\alpha)\left(\gamma_{L}-\gamma_{\theta}\right)\left(V_{Q}-V_{L}\right)
\end{aligned}
$$

(23)式忙(18)式と全く一致している。

以上の思考実験は，気相が連続相で液相が分散相で あっても，また一般に連続相が流れている場合でも全 く同様に成立するむのと考えられる。なお，前節の理 論は二相流の流動様式に無関係に成立する。

\section{4. 壁摩擦力の分配}

本節では，壁摩擦力が気液それそれにどのように分 配されて作用するがついて検討する。

第I-1(1)項で述べたように(3)式の第 4 項は気液 二相流体が壁摩擦力に抗して流れる時の仕事量であ り，換言すれば，壁摩摖エネルギー消散である。をた， 第代2節で述べたように(14)式の第 3 項もまた同しく 暨摩擦エネルギー消散であるから両者は等しくなけれ ばならない。よって

$$
F_{G W} Q_{G}+F_{2 W} Q_{L}=\left(Q_{G}+Q_{L}\right) F_{W}
$$

両边を $\left(Q_{G}+Q_{L}\right)$ て除して $Q_{\sigma} /\left(Q_{\theta}+Q_{L}\right) \equiv \beta$ と掠く と,

$$
\beta F_{\text {OW }}+(1-\beta) F_{L W}=F_{W}
$$

一方, (11)式上り

$$
\alpha F_{O W}+(1-\alpha) F_{L W}=F_{W}
$$

の両式は， $\alpha=\beta$ (これは気液のスリップ比が1である ことを意味する)である場合を除いて， $\alpha, \beta$ の值のい かんにかか和らず常汇成立しなけ机ばならない。その
ための条件は

$$
F_{Q W}=F_{L W}=F_{W}
$$

である。これは，気液それぞれが管壁から受ける摩擦 力は，気液が管壁に接触する面積割合などには関係な く，単位体積当りでは相等しいことを意味する。換言 すれば, “壁摩擦力は気液の体積割合 $\alpha:(1-\alpha)$ と同 じ割合で気液それぞれに分配される”。

このことは，相間摩擦力に関する(19)，(20)式之並 んで，加速のない垂直二相流に関するきわめて重要な 法則といえよう。

(13)式で，壁面で作用する壁摩擦力を流体に体積比 例形の力を及注す生力勾配に置き換兑たことは，壁摩 擦力の分配関する上述の法則が前提とされているの である。

さらに, $F_{z \sigma}, F_{a x}$ は思考実験に上らないでも次の ようにして求められることをつけ加えておく。すなわ ち，(3)式と(14)式より

$$
\begin{aligned}
& \left(\gamma_{G} Q_{G}+\gamma_{L} Q_{L}\right)-\left(F_{G L} Q_{G}+F_{L G} Q_{L}\right) \\
& -\left(F_{G W} Q_{G}+F_{L W} Q_{L}\right) \\
= & \left(Q_{G}+Q_{L}\right)\left\{\alpha \gamma_{G}+(1-\alpha) \gamma_{L}\right\}-\left(Q_{G}+Q_{L}\right) F_{W}=0
\end{aligned}
$$

これに(24)式を代入し， $F_{G L}$ と $F_{L Q}$ の間に(10)式 の関係があることを入れて $F_{G L}, F_{L G}$ を求めると。 (19)，(20)式と同し結果が得られる。

\section{III. 適用例および考察}

\section{1. 円管流路の場合}

前章で述べた理論を実際の二相流に適用するために は，王力損失とボイド率が同時に測定されている必要 がある。本節では垂直におかれた円管流路を上向きに 流れる大気圧の空気一水二相流について，斯波らの春 験データ(1)22を用いて検討してみる。本実験は，内径 $24.5 \mathrm{~mm}$, 軸長 $1,350 \mathrm{~mm}$ のテスト部について行われた あので，テスト区間の平均ボイ、ト率は，連動する 2 個 の急速遮断弁によりポイドをテスト管内に閉じ込めて 測定したものである。流動様式は肉眼観察により判断 している。な特，本実験は大気圧下で行われているた め，テスト管内の殴力降下に基つく空気の比体積の増 加の影響を無視することはできない。本報で採用した データについて，この比体櫴の增加は最大 $14 \%$ 程度と 見込まれる。このことにより相間摩擦エネルギー消散 に生ずる䛊差はきわめて小さいが，壁摩擦および全非 可逆エネルギー消散については，加速仕事分を含むの で実際より大きめ算出する傾向があり，とくに水流 量, 空気流量がともに大きい所で，その影響が大きい ものと考光られる。 
第 3 图は， $E_{r}$ を気液の平均流速 $\bar{V}\left(=\left(Q_{\theta}+Q_{L}\right) /\right.$ A)に対してブロットしたもので，世古口の結果(3)と 大差ないりのである。これによれば，平均流速が 1.5 $\mathrm{m} / \mathrm{sec}$ 以下では，水流量が小さい注ど非可逆エネル ギー消散が大きいのに対して，平均流速が $3.0 \mathrm{~m} / \mathrm{sec}$ 以上ではこの関係が逆転している。また，水流量が $0.166 \mathrm{~kg} / \mathrm{sec}$ (管の単位断面積当 り $355 \mathrm{~kg} / \mathrm{m}^{2} \cdot \mathrm{sec}$ )以 下では, $\bar{V} か ゙ 1 \mathrm{~m} / \mathrm{sec}$ 以下で曲線が嘻らむ傾向を見せ ている。

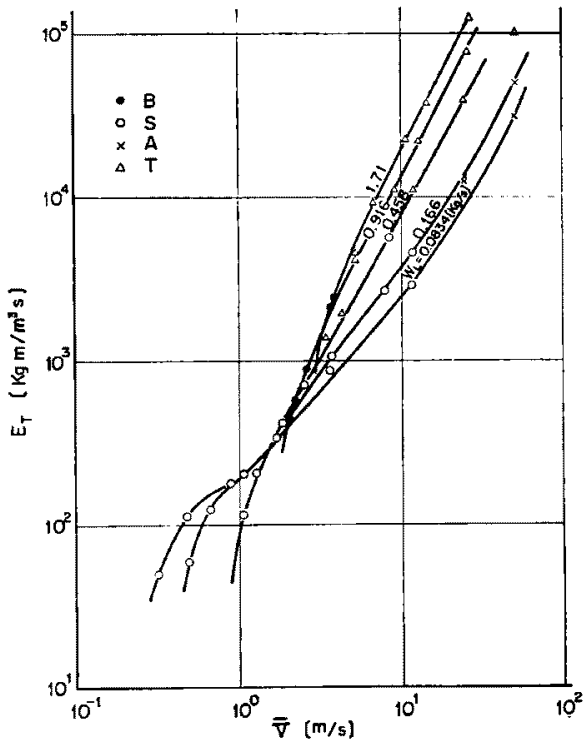

第 3 図 管流路における水流量をパラィ一タ とした，全非可这エネルギー消散量と 気液の平均流速との関係

第 4 图は前园の $E_{T}$ を $E_{I}$ と $E_{\text {W }}$ に分離したすので ある。図中 B， S，A，T の略記号は流動棁式を示し， B は気泡流，Sはスラグ流，Aは環状流，Tは乱れ流を 意味している。これによれば，水流量が $0.916 \mathrm{~kg} / \mathrm{sec}$ (管の単位断面皘当り $1,950 \mathrm{~kg} / \mathrm{m}^{2} \cdot \mathrm{sec}$ ) 以上では, $E_{W}$ の增大とともに $E_{I}$ はどこまでる增大しているが，水 流量が $0.166 \mathrm{~kg} / \mathrm{sec}$ 以下では $E_{I}$ は極大点を過ぎれ ば， $E_{W}$ の增大ととるに減少する傾向を示すことがわ かる。この時の流動様式の变化を見ると，前者では気 泡流から Turbulent flow(以下これを乱れ流々呼ら) に透移するのに対して，後者ではスラク流から環状流 に透移士る。水流量か $0.458 \mathrm{~kg} / \mathrm{sec}$ (管の単位断面楥 当り $979 \mathrm{~kg} / \mathrm{m}^{2} \cdot \mathrm{sec}$ )の例では，非可逆エネルギー消散 の分配特性は上記の 2 者の中間に位置し，流動様式る スラク流から乱れ流僊移している。

次に, $E_{\Perp}$ はスラグ流のような，水流量も空気流量も

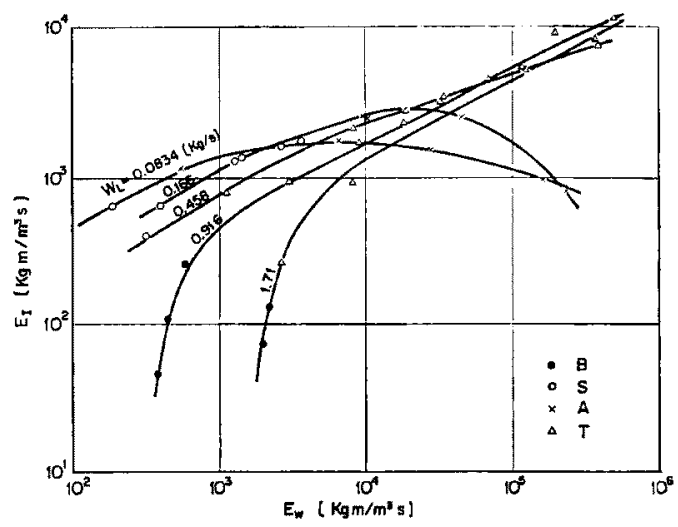

第 4 図 円管流路における，水流量をパラメータ とした，管壁摩擦エネルギー消散と相間 摩擦エネルギー消散との関係

ともに小さい場合には $E_{W}$ の值をしばしば上回るが， 環状流中乱れ流のよらに空気流量が大きい場合には $E_{W}$ の值に比べてかなり小さくなることがわかる。こ のことから，高速二相流については，非可逆エネルギ 一消散の大部分が管壁摩㩐エネルギー消散であると考 えてもおそらく大きな間違いはないものと思われる。

第 5 图は，前図の空気の低流量範囲のみを平等目盛 で示したものである。スラグ流のデータの中には管壁 摩擦エネルギー消散が負のものが多数見られる。も し，実際に $E_{\text {W }}$ が負になるとすれば，(2)式で $d P_{f}>$ 0 ，すなわら(1)式で $F_{W} d Z>0$ なることを意味し， 管壁付近で流机か下向きになっていることを示するの である。このことについては今後さらに検討する必要

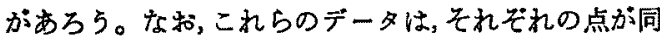
一流量条件下での 7 回の測定結果の平均値であって， かなり信頼のおけるものであることを付記する。

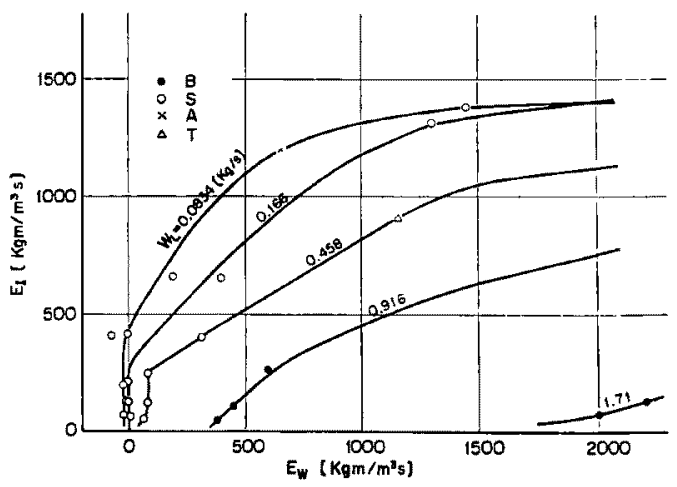

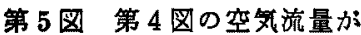
少ない場合の関係 
第 6 图は， $E_{\text {W }}$ を水の線速度 $V_{L}\left(=Q_{L} / A(1-\alpha)\right)$ に対してプロットしたものである。この場合も，水流 量が $0.166 \mathrm{~kg} / \mathrm{sec}$ 以下では他と違った特性が見られ る。困中の破線は Blasius の式による $E_{\text {W }}$ の計算值 を示す。環状流のごく一部のデータを除けば，二相流 の管壁摩擦エネルギー消散の方が同一線速度の水単相 流のそれよりす最大で15倍る大きいことがわかる。

\section{2. 管束型原子炉燃料体の場合}

流れ方向压力勾配によるボイド率変化の影響をな るべく小さくする目的で，約 $4 \mathrm{~kg} / \mathrm{cm}^{2} \cdot \mathrm{g}$ に加正され た空気一水二相流による JPDR-I およびATR 用軽水

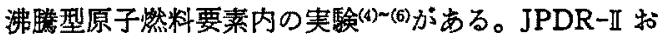
よびATR の各燃料体流路断面図を第 7 图と第 8 図に 示す。図中 $A_{b}$ は流路断面積, $d_{m}$ は水力直径を示す。 JPDR-II の場合は燃料棒の長さ約 $1,630 \mathrm{~mm}$ の間に燃 料棒整列用スペーサーが間隔約 $540 \mathrm{~mm}$ で 2 段入って いる。ATRの場合は然料棒の長さ約 $4,100 \mathrm{~mm}$ の間炕 スペーサーが間隔約 $410 \mathrm{~mm}$ で9段入っている。ATR (2 次設計)は流路断面については 1 次設計と然料棒径 および配列の仕方は同じであるが，王力管内径が117.8

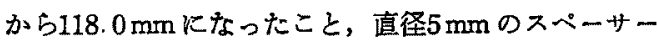

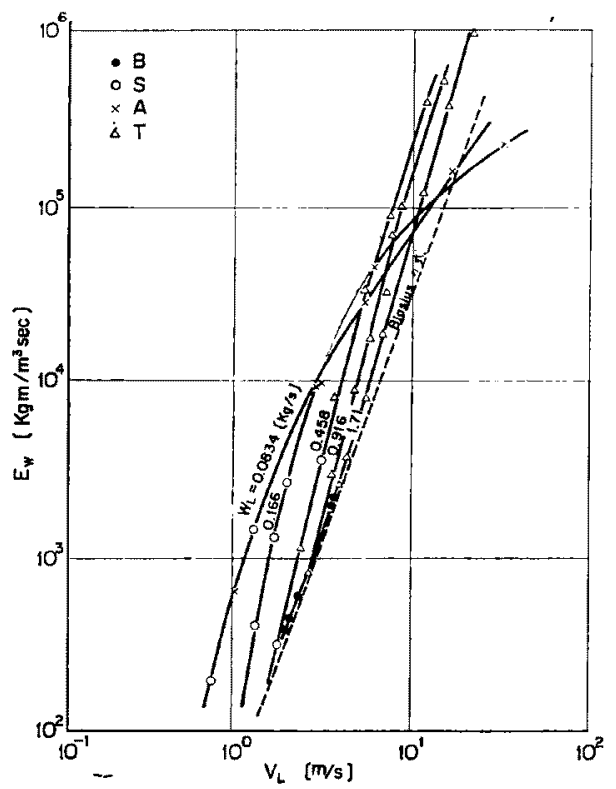

第 6 図 円管流路における，水流量をパ ラメータとした水の線速度と管 壁摩擦エネルギー消敬との哭保

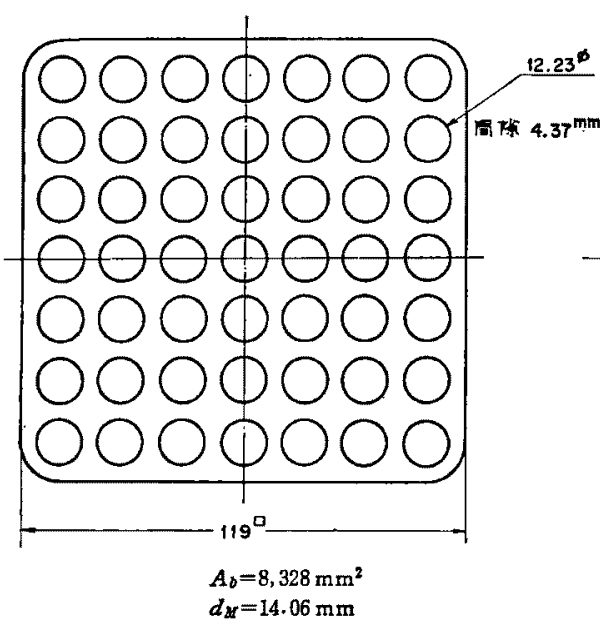

(a) JPDR-II 用然料要素(49本)

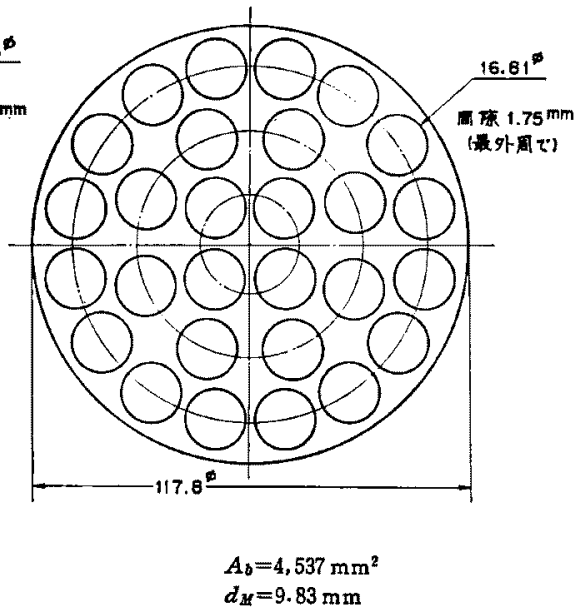

(b) ATR 用然料要素(28本)

第 7 图 JPDR-II およびATR 用燃料要素の流路断面図

タイロッドの位值が同心円の 1 列目と 2 列目の間に 4 本あったすのが， 2 列目と 3 列目の間に 4 本怙くこと になったことの 2 点の変更がなされた。これらの管束 流路での結果を円管の場合と同様にプロットしたもの を第 9 〜 13図炕示す。

な拉，流動状態性，これらの管束流路の上らに水力 直径*は小さいが流路断面積は大きい流路ではスラク
流や環状流になりにくく、これらの実験範囲ではすべ ての流量でボイド率が約60\%をですべて気泡流であっ た。

第 8 図は，JPDR-I の場合の $E_{I}$ と $E_{W}$ の関係であ

* 水力直径 $d_{M}$ 性 $d_{H}=$ (流路断面稓 $\times 4$ )/(流路の 的緗長さ)で表わされるるのである。 


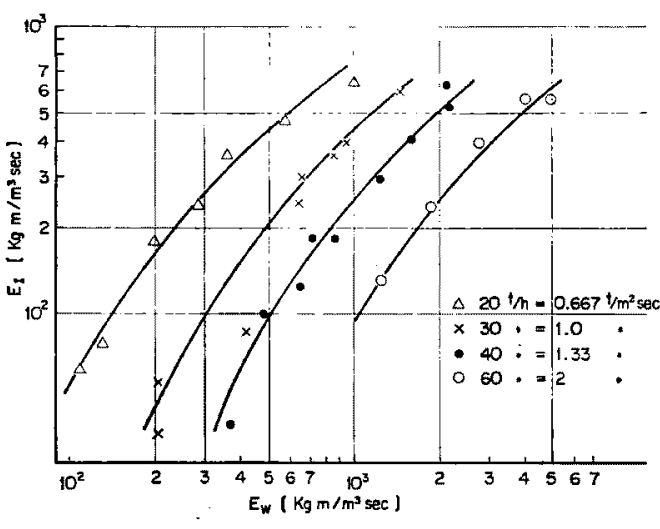

第 8図 JPDR-IIの場合の壁摩擦エネルギー消散 と相間摩擦エネルギー消散との関低

り，円管と同じ単位面積当りの水流量で比較すると， 気泡流では $E_{T}$ の增大に伴ら $E_{I}$ の増大の割合は円管 の方が大きいが，円管の場合はボイド率の增加によっ て乱れ流あるいは環状流になりやすく，そのためこの 勾配は非常に緩やかになる。しかし，管束流路ではボ イド率が増大してす流動状態は気泡流の状態を保つの で， $E_{I}$ の $E_{W}$ に対する公配は楥やかにならない。し たがって，ボイド率の低い所では同じ単位面積当りの 水流量と同じ $E_{W}$ に対しては円管の場合の方が $E_{I}$ は
少し大きいがボイド率が増加し，円管の流動状態が 変化して勾配が緩やかになるとある所で逆に管束流路 の方が大きくる。しかし，同じ管束流路でもATR の場合は，1 次設計(第 9 图(a))でる2 次設計(第 9 図 (b))でも $E_{I}$ の $E_{W}$ に対する勾配は JPDR の場合に 此へてやや急であるが， $E_{I}$ の大きさと $E_{I}$ の $E_{W} に$ 対する割合は本夷験範囲においては小さい。

第 9 図(a)と(b)妾比較すると，(b)の 2 次設計のるのの 方が勾配がやや急である。

以上の3つの管束流路には水力直径の差異のほかに 然料棒の配列状態やスペーサー形式の相違などがあっ て一概にはいえないが，大よその㑯向として，水力直 径が小さくなると $E_{I}$ の $E_{W}$ に対する割合が小さくな っている。

次に, JPDR-II の場合(第10図)とATR 1 次設計の 場合(第 11 図)での，二相流の液相速度 $V_{x}$ に対する

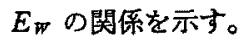

第10図では，円管での環状流を除いた場合とほぼ同 じ傾向を示し，Blasius の式より求められる $E_{W}$ の值 よりむ大きい谊となっている。これに反して，第11国 では Blasius の式とほぼ等しい値になっている。この 理由として，次の 2 つが考光られる。

第 1 に，(15)式で明らかなよらに， $E_{w}$ の值は気液

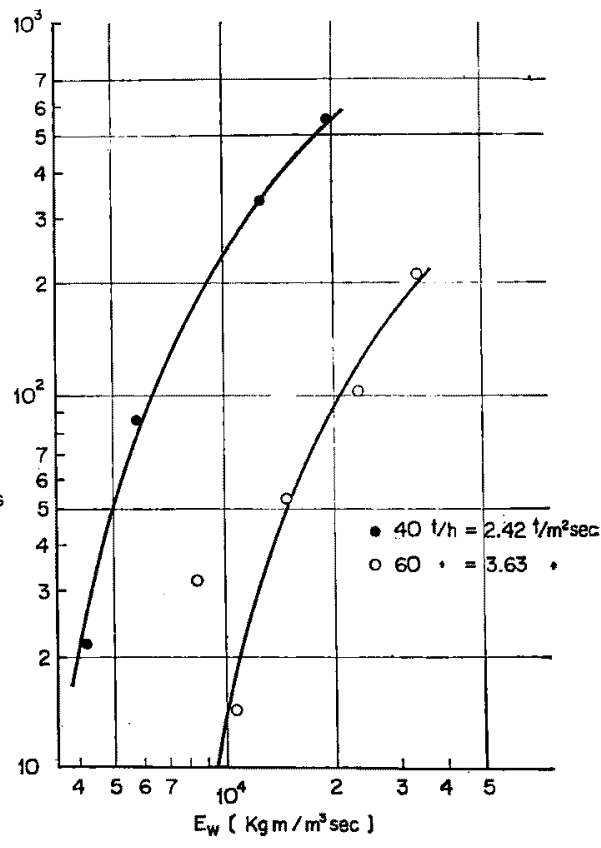

(b) 2 次設計燃料要索

(a) 1 次設計燃料要素

$\times 30 t / m=1.85 \%$

- $40 \cdot=2.47$.

$\nabla 50,=3.09$,

$\circ 60+=3.7$

10

$10^{3}$

(1)

第 9 図 ATR 㜣料要索に蚂ける壁摩擦エネルギー消散と相間摩擦エネルギー消散との関保 


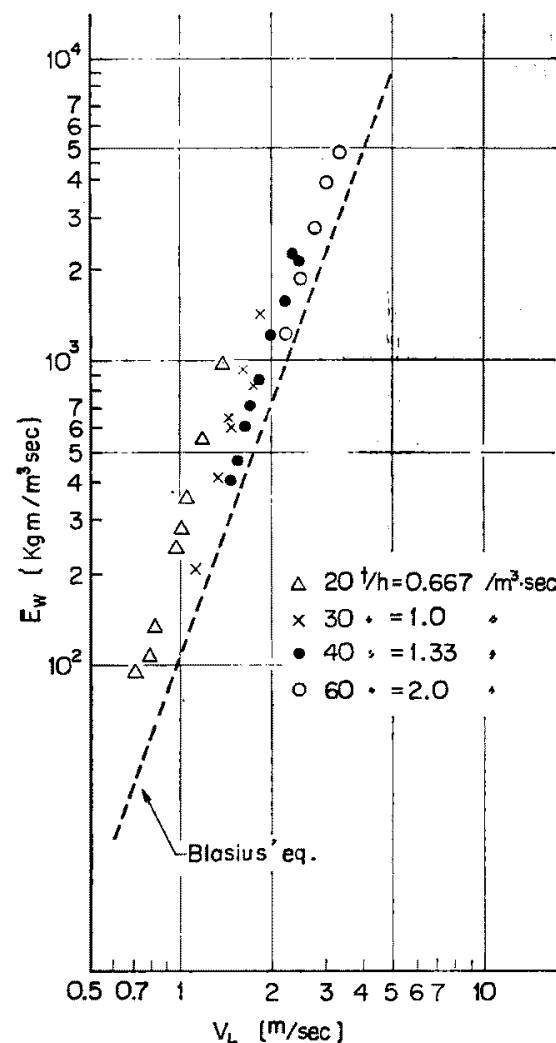

第10図 JPDR-II皆合の二相流の液相速度 と壁摩擦エネルギー消散との関係

の平均流速 $\left(Q_{G}+Q_{L}\right) / A$ 之壁摩摖压力降下 $d P_{f} / d Z$ とに比例するが，第 10 図の JPDR-II の例では気液の すべりが大きいため $\left(Q_{G}+Q_{L}\right) / A$ が液相速度 $V_{L}$ に 比べてかなり大であるのに，第 11 四のATRの例で は，気液のすべりが小さいためこれらがあまり違かな い值をとることである。

第 2 K, ATR の例では $d P_{f} / d Z$ の値が Blasius の 式に比へでさいことである。第12図に，ATRの場 合の液相基集のレイノルズ数 $R e_{2}$ 之摩擦係数 $\lambda$ との 関係を示す。因はいくつかの水流量について空気流量 を增加させていき，それに伴って增加する $R e_{2} に$ 対し てれをプロットしたるのである。第12図によると，単 相流では Blasius の式に一致するすのか，二相流にな ると空気流量がごく小さい所では空気流量の增大とと るに入は急激に增大するが，空気流量がさらに大きく なるとこの上昇率は段々小さくなり，ついにはlasius の式よりも小さい入となる。この傾向は水流量の大き い所でとくに著しく，わずかの空気流量の增大によっ てすぐに Blasius の式より小さなんとなってしまう。

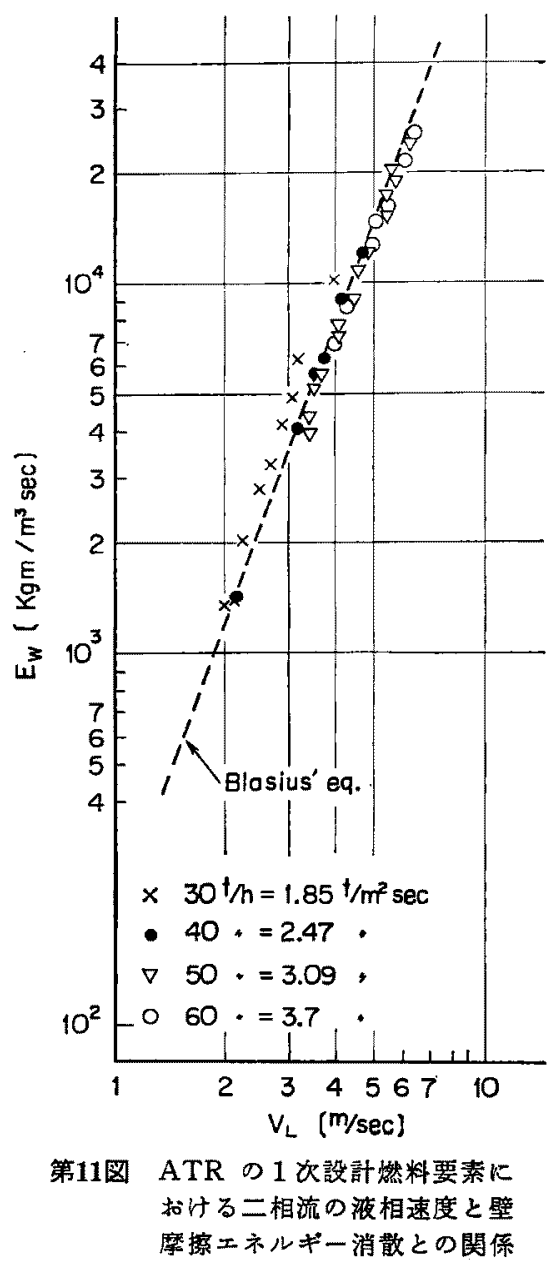

このように, ATR 燃料の場合に $\lambda$ の值が Blasius の式に比ぺて小さくなる理由として考えられることは

(1) ATR 然料体では水力直径が小さいため，管壁 近くの比較的速度勾配が急なところにも気泡が入 り込んでくると予想されること。

(2) ATR 燃料体では然料棒配列が多少不規則で, 棒間箵の広い所と狭い所とがあり，いわゆるサブ チャンネル効果があると考えられる。すなるち， サブチャンネル相互間で流速やボイド率ならびに すべり比などに差があると予想されること。

(3)これらの結果として，二相流では全机縁が等 しい流れのせん断力を受けると仮定して求められ る水力直径を使用すること作無理があると考えら れる。とくに，サブォャンネル効果のある ATR 然料体のような場合には，通常の水力直径をその 


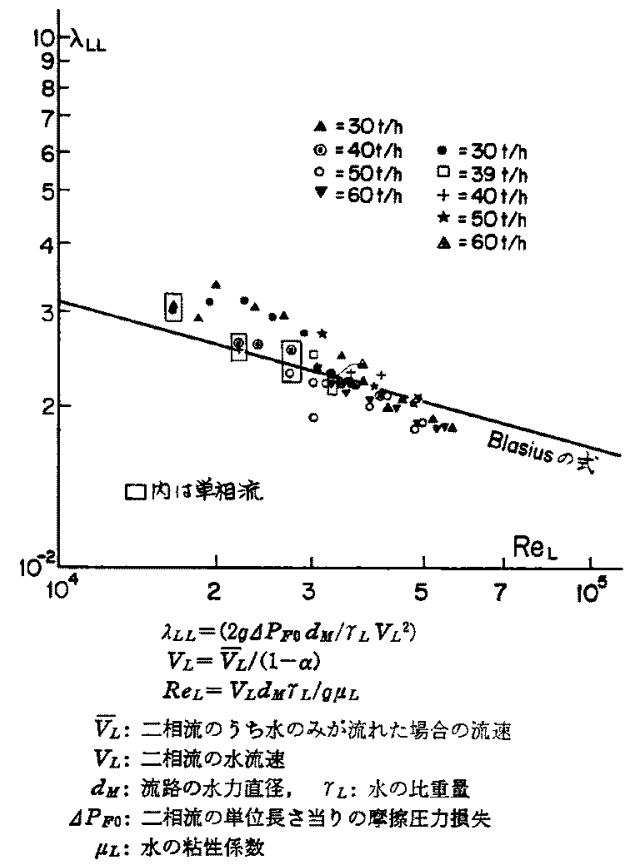

第12图 ATRの1次設計燃料要素に打ける 液相速度蕉準のレイノルズ数と摩擦 保数との関係

ます導入することに問題がある。 なとのことが挙げられる。これらの点については今後 さらに検討を加光る必要があろう。

\section{IV. 結 論}

相変化のない垂直二相流の全非可近エネルギー，壁 摩擦エネルギーおよび相間摩擦エネルギーの消散を求 める関係式(6)，(17)，(18)を導いた。相間摩摖エネル ギ一消散の式については，二相流の位置水頭の意味を 思考実験によって分析することにより直接導かれるこ とを示した。また，加速のない気液二相流の各相に加

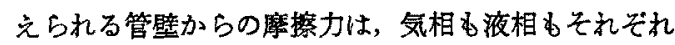
単位体積当りには等しい力で分配されねばならないこ とが理諭的に尊かれた。

これらの式を用いて夷験值を整理することにより， 円管流路については以下のことが明らかになった。

（1）水流量を一定に保ったま空気流量を增加させ た時，気泡流から乱れ流に変化する流れ(1,950 $\mathrm{kg} / \mathrm{m}^{2} \cdot \mathrm{sec}$ 以上)では, 管壁摩擦エネルギー消散の 増大とともに相間摩擦エネルギー消散もどこまで る增大する。 また，スラグ流から環状流に遷移する流れ(355 $\mathrm{kg} / \mathrm{m}^{2} \cdot \mathrm{sec}$ 以下)では, 管壁摩擦エネルギー消散の 堌大ととるにある極大点に達し，それ以後は減少 する傾向を示す。

そして，スラグ流から乱れ流に㖶移する流れは 上記 2 者の中間の水流量の場合に起り，管壁摩摖 エネルギー消散の增加に伴ら相間摩擦エネルギー 消散の変化の仕方も上記 2 者の中間位值する。

（2）水流量も空気流量もと6に小さく，流動様式加 スラグ流になるような二相流では，管壁摩䏅エネ ルギー消散は非常に少なく, 相間摩擦エネルギー 消散の方が多い領域が存在するが，高速二相流で は非可逆エネルギー消散の大部分を管壁摩摖エネ ルギー消散が占める。

(3) 同一平均液流速の単相流と二相流のそれぞれに 㧍ける管壁摩摖エネルギー消散を比較すると, 二 相流の方が水単相流のそれよりるずっと大きく， 最大で約15倍も大きいことがある。ただし，これ は管壁にお汀る摩擦力が15倍大きいことを意味す るのではなく，(15)式に示されるように，気液の 平均体積流量あるいは二相流の気液のすべりの大 きさに関係している。

また，管束流路については次のことが明らかとなっ た。

(4) 相間摩擦エネルギー消散す管壁摩擦エネルギー 消散もともに円管の場合の環状流以外の便向之同 し傾向を示すが，水力直径が小さくなるか，管束 の配監の状態が不均一で管束流路内に大小のサブ チャンネルが形成されるような流路では，管壁摩 擦に比較して相間摩擦によるエネルギー消散は少 なくなる。

\section{[記号]}

$A ：$ 流路断面積

$E:$ 二相流路単位体稓当り，単位時間当りに生ずる 摩擦エネルギー消散量, または流体が摩擦力に 抗してなす任事量

$F$ : 単位体積の流体に作用する摩擦力

$h:$ エンタルピー， $J:$ 熱の仕事当量

$P$ : 压力, $Q$ : 体稓流量, $S:$ エントロピー

$V:$ 流断面に扰ける平均流速, $v$ : 此容積

$Z$ : 流れに浻った軸(距離)， $\alpha$ : ボイド率

$r:$ 比重量

(添 字)

$G ：$ 気体，GL：気体が液体から受ける

$L$ : 液体，LG：液体加筑体加受ける 


\section{$I:$ 二相の境界面，W：管 壁}

本研究に際して区力損失㧍よびボイド率についての 生データをお貸しいただいた日本原子力研究所安全工 学第一研究室長斯波正誼氏，ならびに本報をまとめる に当り有益なご討論とご助言を頂いた，安全工学部次 長山畸沗三郎氏に潹く感謝いたします。

\section{一考支文献一}

（1）斯波正誼，山椅弥三郎：機械学会論文集，32-240, P. 1231 (1966).

(2) YAMAZAKI, Y., SHIBA, M.: "Cocurrent Gas-Liquid Flow", (1969), Plenum Press.

（3）世古口言彦，他：第 3 回日本伝熱シンポジムム前刷集, (1966).

（4）岡崎元昭, 山崎弥三郎, 新妻 拳: JAERI-memo 3882, (1969)，(末公開).

(5) 同 上: JAERI-memo 4318, (1971), (未公開).

(6) 岡崎元昭, 山崎弥三郎: JPDR-II Progress Rep. No. 13, (1969). $\oslash \Gamma$ 原子力安全」調查専門委員会だよりつ(1976.7.22,第 8 回委員会の講演要旨)

I. 原子力工学試駼センターの設立かよ

II. 軽水炻の改良標準化について。（略）

II. 技街基準改正の概要について。

発電用核燃料物凟比関する技術基準と してはっここれを定める省令は昭和40年に 制定されたすので，またわが国で初めて

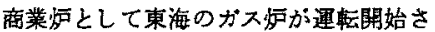
れてから約10年も経過しているので，改 正する必要がある。すた最近軽水少の燃 料に関していボウイング, ニラブス压 損)、ビンホール等のトラブルが起きてお り，種々の検郡が必要であるといること で, 日本電気坫会の部会で約 1 年半の審 議が行われ，50年11月に答申を受けた。 現在まで省内で検討してきたが，むう正 式な省令として出す一歩手前のところま で来ている。

改正の概要では，わが国の発電师はガ

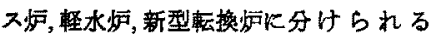
が，(1)ガス沪については現基準による椧 查で充分であると考え，上くに今回の改 正で変更はしない，(2)軽水炣については， ボウインク,コラプス,ビンホールの事象 が起きており，種なな対策がなされてい るが完へきな対策はできていないという ことで，今回の改正は，軽水炉を中心に $\mathrm{UO}_{2}$ 燃料ペレット, $\mathrm{Zr}$ 合金燃料被猫管, 燃 料要素等に関する規定について所要の検 誩を行なった。思想的には従来定生的に なっていたすのを定量的に表現しょ5と い弓努势で作業をしている。近い将来, この基準に䧟合しないスベックや方法の
1974年の ASME Publication が出た段 階で全面的な改正を行なった。主な改正 の内容は，次のとおりである。

(1) ASME K合放せて，現在の技術 基萑の対象である容器,管およひ安 全弁に,ポンプ，ハルブ支持構造物お よび恼心支持構造物を加えた。

（2）機器等のクラス乎けは, NRC Regulatory Guide 1.26, ASME等を 考比て全体を 6 種化分類。

(3) これす ASMEに導入された考え 方であるが，琹耺条件をブラント状

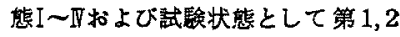
種容器, 第1種管などに探用。

その他の関連事項であるが，発電用新 型少等実用化調查とい5ことで，(1)軽水 师への Pu 利用の実証性調查, (2)新型启 技術基準等確立のための調査，(3)発電用 新型少等の長期利用ビション確立調㚗， を行なっている。データバンクについて は，ラスムッセン報告が出されてから， 信頼度評価方式を確立する必要があると いらことで，通産省では49年度はフォー ルトツリーによる手法，50 年度はマル コフ手法による信頼度解析，51年度はマ ルコフとフォールト・リーを合わせた ような形のプレプキットコードを用いた 信頼度評価法を砤立していく作業をして いる。しかし残念ながら，手法が确立し ても，それに入れるデータが全然ない。 事故や故障とい5法律に基ついて報告さ れる大きなるのはあるが，米国で abnormal occurrance と乎ばれている小さな すのについてのデータが入手できていな いので，信頼度評佂を完全に行らために データバンクを作る必要があるといらこ とで現在科技庁と一舶に作業を進めてい る段階である。 （文責·加藤尚武） 